\title{
EFEKTIVITAS PIDANA PEMBAYARAN UANG PENGGANTI DALAM TINDAK PIDANA KORUPSI (Studi Putusan Tindak Pidana Korupsi di Pengadilan Negeri Purwokerto)
}

\author{
Ade Paul Lukas \\ Barlingmascakeb \\ Purwokerto, Jawa Tengah
}

\begin{abstract}
This punishment is proved not effective because there were only two person punished who repaid. The rest failed to do so due either to lack of money or liquid assets. Instead they signed a letter stating their inability to repay the corrupted money and their readiness to undergo subsidiary punishment. The verdicts of Purwokerto regential Court against corruption act during the period between 2004 through 2008 stated that the punished were given additional punishment to repay the corrupted money but not all of them were punished with such additional punishment. The punishment given was without the obligation to repay and verdict of not guilty. There was constraint from the legal aspect. The constraining factors were the difficulty the public attorney faced in tracing the wealth obtained from corruption. There was also the unawareness of the society to report corruption act.
\end{abstract}

Keyword : Legal effectiveness, Repay the corrupted money, Corruption

\begin{abstract}
Abstrak
Pelaksanaan pembayaran uang pengganti dalam tindak pidana korupsi dapat dikatakan belum efektif karena hanya terdapat 2 (orang) terpidana yang membayar uang pengganti. Hal ini dapat terlihat dengan keadaan terpidana yang tidak mampu membayar, tidak mempunyai harta benda guna menutup pembayaran uang pengganti, adanya surat pernyataannya yang menerangkan tidak mampu membayar uang pengganti dan mampu melaksanakan pidana subsider. Putusan Pengadilan Purwokerto dalam perkara tindak pidana korupsi tahun 2004-2008 dinyatakan bahwa terpidana dijatuhi pidana tambahan berupa pembayaran uang pengganti, namun dalam putusan tersebut tidak semua terpidana dijatuhi pidana tambahan berupa pembayaran uang pengganti, tapi ada pula putusan penjatuhan pidana tanpa pembebanan uang pengganti dan putusan bebas. Ada hambatan dari aspek legal. Hambatan dari faktor penegak hukum berupa kesulitan untuk melacak harta benda milik terpidana yang diperoleh dari hasil tindak pidana korupsi. Hambatan dari faktor masyarakat, kurangnya kesadaran dari masyarakat untuk melaporkan atau memberitahukan tindak pidana korupsi kepada penegak hukum terhadap orang yang dicurigai melakukan tindak pidana korupsi masih kurang.
\end{abstract}

Kata Kunci : Efektivitas hukum, pidana pembayaran uang pengganti, korupsi

\section{Pendahuluan}

Korupsi merupakan perbuatan yang sangat merugikan keuangan negara dan masyarakat sehingga dapat menghambat jalannya pembangunan nasional, oleh karena itu segala macam perbuatan yang sifatnya merugikan keuangan negara perlu dikikis habis di antaranya adalah dengan cara memaksimalkan daya kerja dan daya paksa peraturan perundang-undangan yang ada melalui penegakan hukum.
Pelaku tindak pidana korupsi diidentifikasikan sebagai konspirasi antara pejabat negara dan masyarakat yang bersifat sangat kompleks, sehingga di berbagai negara maju muncul istilah political corruption. Istilah ini berkembang karena mengandung keprihatinan para ahli dan warga negara yang baik karena tindak pidana korupsi ini menurunkan kepercayaan masyarakat terhadap pemerintah secara substansial, di samping mengakibatkan mening- 
katnya biaya pelayanan sosial dan sebaliknya menurunkan kualitas pelayanan sosial. ${ }^{1}$

Salah satu unsur dalam tindak pidana korupsi ialah adanya kerugian keuangan negara. Terhadap kerugian keuangan negara ini, Pemerintah membuat Undang-Undang Korupsi, baik yang lama yaitu Undang-Undang Nomor 3 Tahun 1971 maupun yang baru yaitu UndangUndang Nomor 31 Tahun 1999 Jo Undang-Undang Nomor 20 Tahun 2001, menetapkan kebijakan bahwa kerugian keuangan negara itu harus dikembalikan atau diganti oleh pelaku korupsi.

Undang-Undang Nomor 31 Tahun 1999 tentang Peberantasan Tindak Pidana Korupsi memberi batasan bahwa yang dimaksud dengan korupsi adalah "setiap orang yang secara melawan hukum melakukan perbuatan memperkaya diri sendiri atau orang lain atau suatu korporasi yang dapat merugikan keuangan Negara atau perekonomian Negara". ${ }^{2}$

Menurut Undang-Undang Korupsi tersebut, pengembalian kerugian keuangan negara dapat dilakukan melalui dua instrumen hukum, yaitu instrumen pidana dan instrumen perdata. Instrumen pidana dilakukan oleh penyidik dengan menyita harta benda milik pelaku dan selanjutnya oleh Penuntut Umum dituntut agar dirampas oleh Hakim. Instrumen perdata di lakukan oleh Jaksa Pengacara Negara (JPN) atau instansi yang dirugikan terhadap pelaku korupsi (tersangka, terdakwa, terpidana atau ahli warisnya bila terpidana meninggal dunia). Instrumen pidana lebih lazim dilakukan karena proses hukumnya lebih sederhana dan mudah.

Dalam putusan Pengadilan Negeri, selain pidana pokok biasanya hakim juga memutuskan pidana tambahan berupa pidana uang pengganti kepada para terpidana kasus kejahatan korupsi. Pidana uang pengganti yang dihubungkan dengan jumlah masa tahanan terpidana, kadang kala tidak di penuhi oleh terpidana, di mana mereka lebih memilih pidana tambahan berupa kurungan badan dibandingkan dengan pidana

\footnotetext{
1 Muladi, 1990, Beberapa Dimensi dari Tindak Pidana Korupsi, Suatu Makalah Penataran Nasional Hukum Pidana IV. Purwokerto: Fakultas Hukum UNSOED, hlm. 2

2 Krisna Harahap, 2006, Pemberantasan Korupsi Jalan Tiada Ujung, Bandung: Grafitri, hlm. 2
}

pengganti yang diputuskan oleh hakim yang dapat disebabkan oleh beberapa hal. ${ }^{3}$

Istilah uang pengganti mengandung pengertian yang terkait bukan kepentingan perorangan atau individu, tetapi kepentingan publik atau bahkan kepentingan negara. Dalam hal itu dapat dikatakan criminal and punitive in their nature. Hal ini jelas berbeda sifatnya, misalnya saja dengan tuntutan ganti kerugian karena ditangkap, ditahan, dituntut atau diadili atau dikenakan tindakan lain tanpa alasan yang berdasarkan hukum, karena kekeliruan mengenai orang-nya, hukum yang diterapkan adalah Pasal 95 Kitab Undang-undang Hukum Acara Pidana (KUHAP). Masalahnya juga berbeda dengan gugatan ganti kerugian sebagai akibat perbuatan yang menjadi dasar dakwaan yang dapat digabungkan kepada perkara pidana (Pasal 98 KUHAP). Pada hal ini, yang terkait adalah kepentingan individu, bukan kepentingan negara. ${ }^{4}$

Peraturan perundang-undangan yang berkaitan dengan efektivitas pidana pembayaran uang pengganti dalam tindak pidana korupsi terdapat dalam Pasal 18 Undang-Undang No. 31 Tahun 1999 tentang Pemberantasan Tindak Pidana Korupsi.

Pasal 18

(1) Selain pidana tambahan sebagaimana di maksud dalam Kitab Undang-Undang Hukum Pidana, sebagai pidana tambahan adalah:

a. Perampasan barang bergerak yang berwujud atau yang tidak berwujud atau barang tidak bergerak yang digunakan untuk atau yang diperoleh dari tindak pi-dana korupsi, termasuk perusahaan milik terpidana di mana tindak pidana korupsi dilakukan, begitu pula dari barang yang menggantikan barangbarang tersebut;

b. Pembayaran uang pengganti yang jumlahnya sebanyak-banyaknya sama dengan harta benda yang diperoleh dari tindak pidana korupsi;

c. Penutupan seluruh atau sebagian perusahaan untuk waktu paling lama 1 (satu) tahun;

\footnotetext{
3 Ibid., hlm. 6

4 Muladi, loc.cit.
} 
d. Pencabutan seluruh atau sebagian hakhak tertentu atau penghapusan seluruh atau sebagian keuntungan tertentu, yang telah atau dapat diberikan oleh Pemerintah kepada terpidana.

(2) Jika terpidana tidak membayar uang pengganti sebagaimana dimaksud dalam ayat (1) huruf b paling lama dalam waktu 1 (satu) bulan sesudah putusan pengadilan yang telah memperoleh kekuatan hukum tetap, maka harta bendanya dapat disita oleh jaksa dan dilelang untuk menutupi uang pengganti tersebut.

(3) Dalam hal terpidana tidak mempunyai harta benda yang mencukupi untuk membayar uang pengganti sebagaimana dimaksud dalam ayat (1) huruf $b$, maka dipidana dengan pidana penjara yang lamanya tidak melebihi ancaman maksimum dari pidana pokoknya sesuai dengan ketentuan dalam undangundang ini dan lamanya pidana tersebut sudah ditentu-kan dalam putusan pengadilan.

Hukuman tambahan masih harus dilakukan walaupun ancaman hukuman pokoknya sudah mencantumkan denda yang maksimumnya mencapai Rp 1.000.000.000,- (satu milyar rupiah), bisa saja dalam kenyataannya hasil korupsi yang ada menimbulkan kerugikan negara lebih dari Rp 1.000.000.000,- (satu milyar rupiah), oleh karena itu pidana tambahan berupa kewajiban terhadap terpidana untuk membayar uang pengganti dengan jumlah mak-simum sebesar jumlah harta benda yang diperoleh dari perbuatan yang dilakukannya serta dituntut dan dikenakan pada setiap kasus tindak pidana korupsi sebagai salah satu upaya aparat penegak hukum untuk mengembalikan keuangan negara yang ditimbulkan dari tindak pidana korupsi. ${ }^{5}$

Sehubungan dengan uraikan dalam latar belakang di atas penulis tertarik untuk melakukan kajian yuridis tentang efektivitas pelaksanaan pembayaran uang pengganti dalam tindak pidana korupsi, studi putusan tindak pidana korupsi di Pengadilan Negeri Purwokerto.

\footnotetext{
5 Hendarman Supandji, 2006, Substansi Uang Pengganti dalam Tindak Pidana Korupsi, Makalah Penataran Tindak Pidana Korupsi) Puslitbang Kejaksaan Agung R.I. tanggal 56 Juli 2006.
}

\section{Permasalahan}

Ada dua permasalahan yang coba dicarikan jawab. Pertama, mengenai efektivitas pelaksanaan pembayaran uang pengganti dalam tindak pidana korupsi di Pengadilan Negeri Purwokerto; dan kedua adalah mengenai faktor-faktor yang menjadi kendala efektivitas pelaksanaan/eksekusi pidana pembayaran uang pengganti dalam tindak pidana korupsi di Kejaksaan Negeri Purwokerto.

\section{Metode Penelitian}

Metode pendekatan yang digunakan adalah yuridis sosiologis, dengan spesifikasi penelitian bersifat deskriptif. Sumber data dalam penelitian ini berupa sumber data primer dan sekunder. Lokasi penelitian di Purweokerto, dengan metode pengumpulan data berupa wawancara dan studi pustaka. Data yang diperoleh disajikan dalam bentuk uraian yang di susun secara sistematis, logis dan rasional, kemudian data tersebut dianalisis dengan analisis kualitatif.

\section{Hasil Penelitian dan Pembahasan}

Efektivitas pelakasanaan pembayaran uang pengganti dalam tindak pidana korupsi di Pengadilan Negeri Purwokerto

Perkembangan ilmu hukum pada umumnya dan praktiknya seringkali menimbulkan masalah yang menyangkut keberadaan kaidah hukum dan efektivitas kaidah-kaidah hukum dengan menge-tengahkan efektivitas hukum. Artinya efektivitas hukum akan disoroti dari tujuan yang ingin di capai. Efektivitas mengandung arti "keefektif-an" (efectiveness) pengaruh/efek keberhasilan, atau kemanjuran/ kemujaraban. ${ }^{6}$ Oleh karena itu dalam membahas permasalahan efektivitas penjatuhan pidana pembayaran uang pengganti dalam tindak pidana korupsi, maka didalamnya terkandung masalah "seberapa jauh perangkat hukum lembaga penegak hukum yang ada selama ini cukup efektif/berpengaruh/berhasil guna dalam pelaksanaan pidana pembayaran uang

\footnotetext{
6 Barda Nawawi Arief, 2003, Kapita Selekta Hukum Pidana, Bandung: Citra Aditya Bakti, hlm. 85
} 
pengganti dalam perkara tindak pidana korupsi".

Dikemukakan oleh Barda Nawawi Arief, jika membicarakan efektifitas hukum untuk menanggulangi kejahatan (korupsi) tentunya tidak terlepas dari penganalisaan terhadap karakteristik dan variabel yang terkait, yaitu karakteristik objek/sasaran yang dituju dan karakteristik dari "alat/sarana yang digunakan" (perangkat hukum pidana). ${ }^{7}$ Sedangkan efektivitas hukum tidak dapat dilepaskan dari tipetipe penyelewengan atau delik yang ada dalam masyarakat. Tipe-tipe penyelewengan tersebut merupakan kategorisasi secara teoritis terhadap berbagai jenis penyelewengan yang terjadi di dalam suatu masyarakat. ${ }^{8}$

Pemikiran tentang penegakan hukum sangat erat kaitannya dengan pemikiran tentang efektivitas peraturan perundang-undangan atau hukum yang berlaku. Hal ini berarti pemikiranpemikiran itu biasanya diarahkan pada kenyataan apakah hukum atau peraturan perundang-undangan yang ada benar-benar berlaku atau tidak. Dalam teori efektivitas hukum mengatakan bahwa efektif tidaknya hukum akan sangat tergantung pada faktor subatansi (peraturan hukum itu sendiri), faktor struktur (aparat penegak hu-kum) dan faktor kultur (masyarakatnya). Ketiga faktor tersebut bersama-sama atau sendiri-sendiri akan mempengaruhi efektif tidaknya suatu hukum. ${ }^{9}$

Untuk memahami efektif tidaknya berlakunya hukum di dalam masyarakat, terhadap komponen-komponen sistem hukum sebagaimana tersebut di atas, Friedman memberi penjelasan sebagai berikut. Pertama adalah struktur, yaitu yang bergerak di dalam mekanisme, misalnya di dalam lembaga peradilan strukturnya membedakan peradilan umum, pengadilan administrasi, pengadilan agama, pengadilan militer, dengan pembagian kompetensi masing-masing. Komponen struktur ini diharapkan untuk melihat bagaimana hukum memberikan pelayanan terhadap penggarapan bahanbahan hukum secara teratur. Kedua berupa

\footnotetext{
7 Ibid.

8 Soejono Soekanto, 1985, op.cit, hlm. 68

9 Sidik Sunaryo, 2005, Kapita Selekta Peradilan Pidana, Malang: Universitas Muhammadiyah Malang. hlm. 10
}

substansi, yang termasuk dalam komponen ini adalah ketentuan-ketentuan dan aturan-aturan hukum, yang tertulis dan tidak tertulis. Setiap keputusan yang mengandung doktrin, keputusan pengadilan, keputusan pembuat undangundang dan keputusan yang dikeluarkan oleh badan-badan pemerintahan. Ketiga, berkaitan dengan kultur, yang terdiri dari nilai-nilai, sikap-sikap yang melekat dalam budaya bangsa. Nilai-nilai yang ada di dalam masyarakat itulah yang dapat dipakai untuk menjelaskan apakah atau mengapa orang menggunakan atau tidak menggunakan proses-proses hukum untuk menyelesaikan sengketanya. ${ }^{10}$

Pasal 10 Kitab Undang-undang Hukum Pidana (KUHP) menentukan bahwa selain pidana pokok, pidana lain yang dapat dikenakan terhadap terpidana yaitu pidana tambahan, termasuk dalam pidana tambahan yang dikenal dalam sistem pemidanaan di luar KUHP yaitu pembayaran uang pengganti yang dikenakan terhadap terpidana. Dalam hal ini pembayaran uang pengganti adalah merupakan suatu kewajiban untuk mengembalikan kerugian yang diderita oleh korban akibat perbuatan pelakunya/terpidana.

Sehubungan dengan permasalahan tentang efektivitas penjatuhan pidana pembayaran uang pengganti dalam tindak pidana korupsi. Salah satu unsur tindak pidana korupsi ialah adanya kerugian keuangan negara. Terhadap kerugian negara ini, Undang-Undang Korupsi, baik yang lama yaitu Undang-Undang No. 3 Tahun 1971 maupun yang baru yaitu UndangUndang No. 31 Tahun 1999 sebagaimana diubah dengan Un-dang-Undang No. 20 Tahun 2001 tentang Pem-berantasan Tindak Pidana Korupsi menetapkan kebijakan bahwa kerugian keuangan negara itu harus dikembalikan atau diganti oleh pelaku korupsi.

Undang-Undang No. 31 Tahun 1999 dibentuk dengan tujuan untuk menyelamatkan keuangan negara serta mewujudkan masyarakat yang adil dan makmur berdasarkan Pancasila dan UUD 1945, pemerintah merasa bahwa perbuatan para pelaku tindak pidana korupsi sudah

${ }^{10}$ Ibid., hlm. 14 
menghambat pembangunan nasional, menghambat pertumbuhan dan kelangsungan pembangunan nasional yang menuntut efisiensi tinggi. Sedangkan dalam Undang-Undang No. 20 Tahun 2001 tentang Perubahan atas Undang-Undang No. 31 Tahun 1999, memandang bahwa tindak pidana korupsi merupakan pelanggaran terhadap hak-hak sosial ekonomi masyarakat secara luas, sehingga digolongkan sebagai kejahatan yang luar biasa.

Dalam usaha untuk menyelamatkan dana pembangunan nasional Undang-Undang No. 31 Tahun 1999 sebagaimana telah diubah dengan Undang-Undang No. 20 Tahun 2001 diharapkan mampu untuk mencegah terjadinya kerugian negara serta dapat mengawasi penyelenggaraan negara agar tetap bersih dan berwibawa sebagaimana diamanatkan oleh rakyat melalui Majelis Permusyawaratan Rakyat di dalam Tap MPR RI Nomor XI/MPR/1998. Kedua tujuan tersebut saling berhubungan erat, keuangan negara tidak terlepas dari tanggung jawab pemerintah, oleh karena itu aparat pemerintah harus bersih dan berwibawa.

Untuk melaksanakan hal tersebut di atas perlu adanya suatu pola atau sistem, yaitu sistem penyelenggaraan hukum pidana (Criminal Justice System). Pidana menempati posisi sentral, hal ini disebabkan oleh keputusan dalam pemidanaan akan mempunyai konsekuensi luas baik yang menyangkut langsung pelaku tindak pidana maupun masyarakat luas. Pidana yang dimaksud adalah penderitaan yang memenuhi syarat-syarat tertentu. ${ }^{11}$

Pada penjatuhan pidana pembayaran uang pengganti dalam tindak pidana korupsi sebagai bentuk pemidanaan tambahan yang ditujukan kepada terpidana tindak pidana korupsi, dimaksudkan untuk mengembalikan kerugian keuangan negara akibat perbuatan yang dilakukan oleh terpidana, sehingga negara sebagai korban di pulihkan haknya oleh pengadilan.

Selain ancaman pidana yang cukup berat (yang dalam beberapa pasal ditentukan ancaman minimumnya) dan pidana denda, dalam rumusan Pasal 18 ayat (1) huruf b Undang-Undang

\footnotetext{
${ }^{11}$ Sudarto, op.cit, hlm. 110
}

No. 1999 tentang Pemberantasan Tindak Pidana Korupsi disebutkan bahwa selain pidana tambahan sebagaimana dimaksud dalam KUHP, sebagai pidana tambahan adalah pembayaran uang pengganti yang jumlahnya sebanyakbanyaknya dengan jumlah harta benda yang diperoleh dari hasil korupsi. Dalam ayat (4) disebutkan: dalam hal terpidana tidak mempunyai harta benda yang mencukupi untuk membayar uang pengganti sebagaimana dimaksud dalam ayat (1) huruf $b$, maka dipidana dengan pidana penjara yang lamanya tidak melebihi ancaman maksimum dari pidana pokoknya sesuai dengan ketentuan dalam undangun-dang ini dan karenanya pidana tersebut harus sudah ditentukan dalam putusan pengadilan.

Sebagaimana ditentukan pada Pasal 10 KUHP, bahwa pidana terdiri atas pidana pokok berupa pidana mati, penjara, kurungan dan den-da, sedangkan pidana tambahan ialah berupa pencabutan hak-hak tertentu, perampasan barang-barang tertentu dan pengumuman putusan hakim.

Selain pidana-pidana pokok seperti tersebut dalam ketentuan KUHP, maka dalam Undang-Undang No. 31 Tahun 1999 tentang Pemberantasan Tindak Pidana Korupsi, terhadap terpidana dikenai pula kewajiban untuk membayar uang pengganti kerugian negara yang nilainya sebesar-besarnya sama dengan uang negara yang dikorupsi, perampasan terhadap barang-barang milik terpidana, perampasan terhadap alat-alat atau hasil korupsi, dan pencabutan hak tertentu.

Dengan demikian dapat dikatakan bahwa kebijakan menetapkan beberapa jenis pidana dalam Undang-Undang No. 31 Tahun 1999, secara garis besar bahwa yang ditetapkan sebagai pidana pokok ialah pidana penjara dan pidana denda, sedangkan terhadap pidana perampasan barang-barang dan pembayaran uang pengganti kerugian negara adalah merupakan pidana tambahan.

Dikemukakan oleh Bagir Manan, keberadaan hukum di dalam suatu masyarakat memiliki arti yang sangat penting sebab di samping hukum berfungsi untuk melindungi masya- 
rakat baik dari tindakan kesewenang-wenangan di antara masyarakat sendiri namun juga untuk menjaga perlakuan tidak adil dari negara kepada masyarakat.

Penegakan hukum sebagai bentuk konkrit penerapan hukum sangat mempengaruhi secara nyata perasaan hukum, kepuasan hukum, manfaat hukum, kebutuhan atau keadilan hukum secara individual atau sosial. Penegakan hukum tidak mungkin terlepas dari aturan hukum, pelaku lingkungan tempat terjadi proses penegakan hukum, maka tidak mungkin ada pemecahan persoalan penegakan hukum apabila hanya melirik pada proses penegakan hukum, apalagi lebih terbatas pada penyelenggaraan peradilan. ${ }^{12}$

Ada beberapa putusan PN Purwokerto yang dijadikan sebagai objek kajian dari penelitian ini. Pertama, Putusan Nomor 112/Pid.B/2004/ PN.Pwt yang menghukum terdakwa untuk membayar uang pengganti sebesar Rp 312.519.018,00 (tiga ratus dua belas juta lima ratus sembilan belas delapan belas rupiah); kedua, Putusan No. 22/Pid.B/2006/PN.Pwt, yang menghukum terdakwa-terdakwa membayar uang pengganti, untuk terdakwa Indra Purnomo, SE, sebesar Rp 32.007.250,- (tiga puluh dua juta tujuh ribu dua ratus lima puluh rupiah) dan untuk ter-dakwa Khanif Fauzi, SAg, sebesar Rp 62.007. 250,(enam puluh dua juta tujuh ribu dua ratus lima puluh rupiah) jika dalam jangka waktu 1 (satu) bulan sesudah putusan pengadilan memperoleh kekuatan hukum tetap terpidana tidak membayar uang pengganti maka harta bendanya di sita dan dilelang untuk menutupi uang pengganti tersebut, bila terpidana tidak bisa membayar uang pengganti tersebut, maka untuk terdakwa Indra Purnomo, SE dipidana penjara selama 7 (tujuh) bulan dan untuk terdakwa Khanif Fauzi, SAg, dipidana penjara selama 1 (satu) tahun

Ketiga, Putusan No. 27/Pid.B/2006/PN. Pwt, yang menghukum terdakwa membayar uang pengganti sebesar Rp 31.444. 790,- (tiga puluh satu juta empat ratus empat puluh empat ribu tujuh ratus sembilan puluh rupiah) dengan ketentuan jika dalam jangka waktu 1 (satu)

12 Bagir Manan, 2005. Varia Peradilan. Majalah Hukum Tahun Ke XX No. 241 Nopember 2005, hlm. 4 bulan sesudah putusan pengadilan memperoleh kekuatan hukum tetap terpidana tidak membayar uang pengganti maka harta bendanya disita dan dilelang untuk menutupi uang pengganti tersebut, apabila tidak bisa membayar uang pengganti tersebut, maka untuk terdakwa dipidana penjara selama 7 (tujuh) bulan; keempat, Putusan No. 73/Pid.B/2006/PN.Pwt, yang menghukum terdakwa membayar uang pengganti sebesar Rp 117.529.000,- (seratus tujuh belas juta lima ratus dua puluh sembilan ribu rupiah) dengan ketentuan jika dalam jangka waktu 1 (satu) bulan sesudah putusan pengadilan memperoleh kekuatan hukum tetap terpidana tidak membayar uang pengganti maka harta bendanya disita dan dilelang untuk menutupi uang pengganti tersebut, bila terpidana tidak bisa membayar uang pengganti tersebut, maka di pidana penjara selama 1 (satu) tahun; kelima, Putusan Nomor 114/Pid. B/2007/PN.Pwt yang menghukum terdakwa untuk membayar uang pengganti sebesar Rp 62.183.000,- (enam puluh dua juta seratus delapan puluh tiga ribu rupiah) paling lambat 1 (satu) bulan setelah putusan ini berkekuatan hukum tetap, dan apabila setelah lewat 1 (satu) bulan terdakwa tidak membayar uang pengganti maka harta kekayaan Terdakwa dapat disita oleh Jaksa dan dilelang untuk membayar uang pengganti, dengan ketentuan dalam hal terdakwa tidak mempunyai harta yang mencukupi untuk membayar uang pengganti, maka akan diganti dengan pidana penjara selama 6 (enam) bulan.

Keenam, Putusan Nomor 117/Pid.B/2007. PN.Pwt., yang menghukum kepada terdakwa untuk membayar uang penganti sebesar $\mathrm{Rp}$ 36.000. 000,- (tiga puluh enam juta rupiah) dan jika dalam waktu 1 (satu) tahun bulan sesudah putusan pengadilan memperoleh kekuatan hukum tetap terpidana tidak membayar uang pengganti, maka harta bendanya disita dan dilelang untuk menutupi uang pengganti tersebut, dan apabila terdakwa tidak membayar uang pengganti tersebut, terdakwa dipidana selama 1 (satu) bulan; ketujuh, Putusan Nomor 118/Pid.B/2007/PN. Pwt, yang memerintahkan kepada terdakwa agar membayar uang peng- 
ganti sebesar Rp 29.750. 000,- (dua puluh sembilan juta tujuh ratus lima puluh ribu rupiah) dan jika dalam jangka waktu 1 (satu) bulan sesudah Putusan Pengadilan memperoleh kekuatan hukum tetap terpidana tidak membayar uang pengganti, maka harta bendanya disita dan dilelang untuk menutupi uang pengganti tersebut, dan bila terdakwa tidak membayar uang pengganti tersebut, terdakwa dipidana selama 1 (satu) bulan; dan kedelapan, Putusan No. 113/Pid.B/2008/PN.Pwt, yang memerintahkan kepada terdakwa agar membayar uang pengganti sebesar Rp 39.165.571,49,- (tiga puluh sembilan juta seratus enam puluh lima ribu lima ratus tujuh puluh satu rupiah empat puluh sembilan sen) dan jika dalam waktu 1 (satu) bulan sesudah putusan pengadilan memperoleh kekuatan hukum tetap terpidana tidak membayar uang pengganti tersebut, maka harta bendanya disita dan dilelang untuk menutupi uang pengganti tersebut, dan apabila terdakwa tidak membayar uang pengganti tersebut, terdakwa dipidana penjara selama 6 (enam) bulan.

Putusan Pengadilan Negeri Purwokerto sebagaimana tersebut di atas pada intinya memuat tindak pidana korupsi, dengan tetap mengikuti pidana pokok yang mengacu pada Pasal 10 KUHP, pidana tambahan dalam UndangUndang No. 31 Tahun 1999 dijatuhkan seiring dengan dijatuhkannya pidana pokok, namun sifatnya tetap merupakan pidana tambahan walaupun dalam Pasal 18 ayat (3) UndangUndang No. 31 Tahun 1999, dinyatakan bahwa dalam hal terpidana tidak mempunyai harta benda yang mencukupi untuk membayar uang pengganti sebagaimana dimaksud dalam ayat (1) huruf $b$, maka dipidana penjara yang lama-nya tidak melebihi ancaman pidana maksimum dari pidana pokoknya sesuai dengan ketentuan dalam udang-undang dan lamanya pidana tersebut sudah ditentukan dalam putusan pengadilan.

Sehubungan dengan efektivitas penjatuhan pidana pembayaran uang pengganti dalam tindak pidana korupsi, berdasarkan hasil penelitian terhadap beberapa putusan Pengadilan Negeri Purwokerto tentang tindak pidana korupsi, dalam putusan tersebut tidak semua terpidana dijatuhi pidana tambahan berupa pem- bayaran uang pengganti, tapi ada putusan penjatuhan pidana tanpa uang pengganti dan putusan bebas. Putusan penjatuhan pidana dengan uang pengganti terdapat dalam Putusan Nomor 112/Pid.B/2004/PN.Pwt; Putusan Nomor 22/Pid.B/2006/PN.Pwt; Putusan Nomor 27/ Pid.B/ 2006/PN.Pwt; Putusan Nomor 73/Pid.B/ 2006/PN.Pwt; Putusan Nomor 114/Pid.B/2007/ PN.Pwt; Putusan Nomor 117/Pid.B/2007/PN. Pwt; Putusan Nomor 118/Pid.B/2007PN.Pwt; dan Putusan Nomor 113/Pid.B/2008/PN.Pwt

Putusan penjatuhan pidana tanpa uang pengganti di Pengadilan Negeri Purwokerto yaitu Putusan Nomor 50/Pid.B/2005/PN.Pwt; Putusan Nomor 21/Pid.B/2006/PN.Pwt; dan Putusan Nomor 40/Pid.B/2007/PN.Pwt

Dalam Putusan Nomor 76/Pid.B/2008/ PN.Pwt, Pengadilan menyatakan melepaskan terdakwa-terdakwa oleh karena itu dari tuntutan pidana (onslag van alle rechtsvervolging). Memulihkan hak terdakwa-terdakwa, dalam kemampuan kedudukan harkat dan martabatnya seperti sedia kala.

Meningkatnya tindak pidana korupsi baik dari segi kwantitas maupun kualitas yang begitu rapi telah menyebabkan terpuruknya perekonomian Indonesia. Untuk itu diperlukan adanya penegakan hukum secara sungguh-sungguh dan bersifat luar biasa. Keinginan atau kehendak pembentuk hukum dalam Undang-Undang No. 31 Tahun 1999 tentang Pemberantasan Tindak Pidana Korupsi, tercantum dalam konsideran yang menyebutkan, pertama, tindak pidana korupsi sangat merugikan keuangan negara atau perekonomian negara dan menghambat pembangunan nasional, sehingga harus diberantas dalam rangka mewujudkan masyarakat adil dan makmur berdasarkan Pancasila dan UndangUndang Dasar 1945; kedua, akibat tindak pidana korupsi yang terjadi selama ini selain merugikan keuangan negara atau perekonomian negara, juga menghambat pertumbuhan dan kelangsungan pembangunan nasional yang menuntut efisiensi tinggi; ketiga, Undang-Undang No. 3 Tahun 1971 tentang Pemberantasan Tindak Pidana Korupsi sudah tidak sesuai lagi dengan perkembangan kebutuhan hukum dalam masyarakat, karena itu perlu diganti dengan Undang- 
Undang Pemberantasan Tindak Pidana Korupsi yang baru sehingga diharapkan lebih efektif dalam mencegah dan memberantas tindak pidana korupsi; dan keempat, berdasarkan pertimbangan tersebut di atas, perlu dibentuk Undang-Undang baru tentang Pemberantasan Tindak Pidana Korupsi.

Dengan diterbitkannya Undang-Undang No. 31 Tahun 1999 tentang Pemberantasan Tindak Pidana Korupsi diharapkan sikap tindak atau perilaku masyarakat tidak lagi melakukan perbuatan yang mengarah pada perbuatan yang dapat dikategorikan sebagai perbuatan korupsi serta memberantas tindak pidana korupsi yang telah terjadi secara lebih efektif. Pasal 18 Undang-Undang No. 31 Tahun 1999, berfungsi sebagai usaha khusus untuk mengharapkan kembalinya uang negara yang telah diambil oleh pelaku tindak pidana korupsi, sehingga hal ini sangat penting sebagai usaha untuk mengembalikan kerugian keuangan negara yang ditimbulkan dari tindak pidana korupsi tersebut.

Dikemukakan oleh Soerjono Soekanto, bahwa suatu sikap tindak perilaku hukum di anggap efektif, apabila sikap, tindakan atau perilaku lain menuju pada tujuan yang dikehendaki artinya apabilka pihak lain tersebut mematuhi hukum. ${ }^{13}$ Undang-undang dapat menjadi efektif jika peranan yang dilakukan pejabat penegak hukum semakin mendekati apa yang diharapkan oleh undang-undang dan sebaliknya menjadi tidak efektif jika peranan yang di lakukan oleh penegak hukum jauh dari apa yang diharapkan undang-undang.

Menurut Selo Sumardjan, bahwa efektivitas hukum berkaitan erat dengan faktor-faktor sebagai berikut. Pertama, usaha-usaha menanamkan hukum di dalam masyarakat, yaitu pembinaan tenaga manusia, alat-alat, organisasi dan metode agar warga-warga masyarakat mengetahui, menghargai, mengakui, dan mentaati hukum; kedua, reaksi masyarakat yang didasarkan pada sistem nila-nilai yang berlaku. Artinya masyarakat mungkin menolak atau menentang atau mungkin mematuhi hukum untuk menjamin kepentingan mereka; dan ketiga, jangka waktu

\footnotetext{
${ }^{13}$ Soerjono Soekanto, op. cit. hlm. 3
}

menanamkan hukum, yaitu panjang pendeknya jangka waktu di mana usaha-usaha menanamkan hukum itu dilakukan dan diharapkan memberikan hasil. ${ }^{14}$

Untuk mengukur efektivitas hukum pada umumnya dan efektivitas penjatuhan pidana pembayaran uang pengganti dalam tindak pidana korupsi tidak boleh hanya melihat efektivitas penyelesaian mengenai pengadilan tindak pidana korupsi saja, hal ini sesuai dengan pendapat yang dikemukakan oleh Ahmad Ali, sebagai berikut : "Efektif atau tidaknya hukum bukan semata-mata ditentukan oleh peraturannya saja, tetapi juga dari dukungan beberapa institusi yang berada di sekeliling peraturan itu, seperti faktor manusianya, faktor kulturnya, faktor keuangannya dan sebagainya". ${ }^{15}$

Penegakan hukum Undang-Undang No. 31 Tahun 1999, bertujuan untuk mengembalikan kerugian keuangan atau perekonomian negara akibat perbuatan pelaku tindak pidana korupsi. Jika ditinjau dari efektivitas daripada keberhasilan dalam pelaksanaan penjatuhan pidana pembayaran uang pengganti dalam tindak pidana di Pengadilan Negeri Purwokerto, maka hal tersebut dapat dikatakan belum efektif terutama dalam hal pembayaran uang pengganti yang dilakukan oleh terpidana.

Dalam putusan penjatuhan pidana tambahan pembayaran uang pengganti terpidana tidak mampu membayar, tidak mempunyai harta benda guna menutup pembayaran uang peng-ganti, adanya surat pernyataannya yang me-nerangkan tidak mampu membayar uang peng-ganti dari terpidana, dan akan menjalani pidana subsidair.

Berdasarkan hasil penelitian terhadap Putusan Pengadilan Purwokerto sebagaimana telah di sebutkan di atas dalam perkara tindak pidana korupsi tahun 2004, 2005, 2006, 2007 dan 2008 dalam putusan tersebut terpidana dijatuhi pidana tambahan berupa pembayaran uang pengganti. Dalam putusan tersebut ternyata tidak semua terpidana dijatuhi pidana

\footnotetext{
14 Ibid., hlm. 9

${ }^{15}$ Achmad Ali, 1990, Mengembara di belantara Hukum, Makasar: Lembaga Penerbit Universitas Hasanuddin. $\mathrm{hlm} .103$
} 
tambahan berupa pembayaran uang pengganti, tapi ada putusan penjatuhan pidana tanpa uang pengganti dan putusan bebas.

Faktor-faktor yang menjadi kendala efektivitas pelaksanaan/eksekusi pidana pembayaran uang pengganti dalam tindak pidana korupsi di Kejaksaan Negeri Purwokerto

Dikemukakan oleh Barda Nawawi Arief, bahwa masalah pembangunan dan penegakan hukum merupakan masalah yang tidak pernah henti-hentinya dibicarakan, baik secara nasional dan internasional. Masalah ini akan selalu dan selalu patut dibicarakan, sepanjang kita masih mengakui adanya negara hukum dan sepanjang kita masih mempercayai hukum sebagai salah satu sarana untuk mengatur dan menyelesaikan masalah-masalah kehidupan bermasyarakat. Terlebih dalam era reformasi saat ini, masalah "wibawa hukum" dan "pemerintahan yang bersih dan berwibawa" sedang mendapat tantangan dan sorotan tajam. ${ }^{16}$

Dilihat dari sudut lembaga pendidikan hukum yang berperan membentuk kualitas Sumber Daya Manusia (SDM) di bidang hukum, maka "peningkatan wibawa hukum" lebih patut diartikan sebagai "peningkatan kualitas Sumber Daya Manusia (SDM) penegakan hukum". Dengan adanya "peningkatan kualitas penegakan hukum" diharapkan ada "peningkatan wibawa hukum". Meningkatnya kualitas penegakan hukum tentunya juga diharapkan dapat menunjang dan meningkatkan "kualitas pemerintahan yang bersih dan berwibawa" serta meningkatkan "kualitas lingkungan hidup/kualitas kehidupan bermasyarakat". ${ }^{17}$

Masalah pelaksanaan/eksekusi pidana pembayaran uang pengganti pada dasarnya juga merupakan masalah penegakan hukum. Terkait dengan faktor-faktor yang menjadi kendala efektivitas pelaksanaan/eksekusi pidana pembayaran uang pengganti dalam tindak pidana korupsi di Kejaksaan Negeri Purwokerto, menurut Satjipto Rahardjo, ada dua fungsi yang

\footnotetext{
16 Barda Nawawi Arief, 2001, Masalah Penegakan Hukum dan Kebijakan Penanggulangan Kejahatan, Bandung: Citra Aditya Bakti, hlm. 13

17 Ibid., hlm. 14
}

dapat dimainkan oleh hukum yakni hukum sebagai social control, dan hukum sebagai social engineering. Selanjutnya Satjipto Rahardjo mengatakan bahwa hukum sebagai kontrol sosial mengandung arti bahwa bertugas untuk menjaga masyarakat tetap berada di dalam pola-pola tingkah laku yang telah diterima olehnya. $^{18}$

Dalam rangka perspektif hukum sebagai social control, fungsi utama sistem hukum bersifat integratif. Maksudnya hukum untuk mengatur dan memelihara regulitas sosial. Tanpa hukum, masyarakat bisa menjadi homo homini lupus (manusia yang satu menjadi serigala bagi manusia lainnya). Tiada masyarakat yang bisa hidup lama tanpa kontrol sosial dari hukum sebagai sarananya.

Dalam fungsinya sebagai a tool of social engineering memberikan dasar bagi kemungkinan hukum dipergunakan untuk mengadakan perubahan masyarakat. Hukum dalam perspektif social engineering-lah yang paling banyak diper-gunakan oleh para pejabat untuk menggali sumber-sumber kekuasaan yang dapat dimobili-sasikan dengan menggunakan hukum sebagai mekanismenya. Upaya pengendalian sosial dengan menggunakan hukum sebagai sarananya itulah, oleh Roscou Pound disebut social engineering (rekayasa sosial). ${ }^{19}$

Untuk menganalisis faktor-faktor yang menjadi kendala efektivitas pelaksanaan/eksekusi pidana pembayaran uang pengganti dalam tindak pidana korupsi di Kejaksaan Negeri Purwokerto, terlebih dahulu perlu dikemukakan di sini pendapat dari Soerjono Soekanto. Dikemukakan oleh Soerjono Soekanto bahwa pada pokoknya masalah tersebut sebenarnya terletak pada faktor-faktor yang mungkin mempengaruhinya. Faktor-faktor tersebut mempunyai arti yang netral, sehingga dampak positif atau negatifnya terletak pada isi faktor-faktor tersebut. Pertama, faktor hukumnya sendiri, yang di dalam tulisan ini akan dibatasi pada peraturan perundang-undangan saja; kedua, faktor

\footnotetext{
${ }^{18}$ Satjipto Rahardjo. 1980, Hukum dan Masayarakat, Bandung: Angkasa, hlm. 117

19 Ronny Hanitijo Soemitro, 1985, Studi Hukum dan Masyarakat. Bandung: Alumni, hlm. 46
} 
penegak hukum, yakni fihak-fihak yang membentuk maupun menerapkan hukum; ketiga, faktor sarana atau fasilitas yang mendukung penegakan hukum; keempat, faktor masyarakat, yakni lingkungan di mana hukum tersebut berlaku atau diterapkan; dan kelima, faktor kebudayaan, yakni sebagai hasil karya, cipta dan rasa yang didasarkan pada karsa manusia di dalam pergaulan hidup. Kelima faktor tersebut di atas saling berkaitan dengan eratnya, oleh karena merupakan esensi dari penegakan hukum, dan juga merupakan tolok ukur dari pada efektivitas penegakan hukum. ${ }^{20}$

Soerjono Soekanto mengemukakan bahwa secara konsepsional, inti dan arti penegakan hukum terletak pada kegiatan menyelesaikan hubungan nilai-nilai yang terjabarkan di dalam kaidah-kaidah yang mantap dan mengejawantah dan sikap tindak sebagai rangkaian penjabaran nilai tahap akhir, untuk menciptakan, memelihara dan mempertahankan kedamaian pergaulan hidup. Konsepsi yang mempunyai dasar filosofis tersebut, memerlukan penjelasan lebih lanjut, sehingga akan tampak lebih konkrit. ${ }^{21}$

Sehubungan dengan faktor-faktor yang menjadi kendala efektivitas pelaksanaan/eksekusi pidana pembayaran uang pengganti dalam tindak pidana korupsi di Kejaksaan Negeri Purwokerto, dapat diuraikan sebagai berikut. Pertama, faktor hukumnya sendiri, yang di dalam tulisan ini akan dibatasi pada peraturan perundang-undangan saja. Dalam pelaksanaan/ eksekusi pidana pembayaran uang pengganti pada dasarnya juga merupakan masalah penegakan hukum. Hukum dapat mencerminkan nilainilai yang menjadi dasar dari hukum itu sendiri agar hukum atau peraturan perundang-undangan tersebut dapat berlaku efektif. Sehubungan dengan hal tersebut, peraturan perundang-undangan yang berkaitan dengan efektivitas pidana pem-bayaran uang pengganti dalam tindak pidana korupsi Undang-Undang No. 1 Tahun 1999 tentang Pemberantasan Tindak Pidana Korupsi, maka dari faktor hukumnya sendiri telah me-

\footnotetext{
20 Soerjono Soekanto, 1993, Faktor-faktor Yang Mempengaruhi Penegakan Hukum, Yakarta: PT. Raja Grafindo Persada, hlm. 6

${ }^{21}$ Ibid., hlm. 3
}

miliki dasar hukum yang kuat sehingga faktor ini tidak menjadi kendala yang menghambat tujuan dari pada undang-undang pemberantasan tindak pidana korupsi dalam rangka mempercepat pemberantasan korupsi di Indonesia.

Dalam penjelasan umum Undang-Undang No. 31 Tahun 1999 dinyatakan bahwa pembangunan nasional bertujuan mewujudkan manusia Indonesia seutuhnya dan masyarakat Indonesia seluruhnya yang adil, makmur, sejahtera, dan tertib berdasarkan Pancasila dan Undang-Undang Dasar 1945. Untuk mewujudkan masyarakat Indonesia yang adil, makmur, dan sejahtera tersebut, perlu secara terus-menerus ditingkatkan usaha-usaha pencegahan dan pemberantasan tindak pidana pada umumnya serta tindak pidana korupsi pada khususnya. ${ }^{22}$

Kedua, faktor penegak hukum, yakni pihak-pihak yang membentuk maupun menerapkan hukum. Pencapaian supremasi hukum harus diukur dari seberapa baik penegakan hukum yang dilakukan di Indonesia, berbicara mengenai penegakan hukum, maka hal paling penting dan mendasar adalah bagimana kemampuan aparat penegak hukum (khususnya dalam bidang tindak pidana korupsi), dalam sistem peradilan dapat mengakomodasi dan mengapresiasi tuntutan keadilan baik yang menjadi ruh hukum formal maupun tuntutan rasa keadilan oleh masyarakat dalam pemberantasan korupsi merupakan suatu kebutuhan dasar. ${ }^{23}$

Dikemukakan oleh Soejono Soekanto, sebagai salah satu faktor yang menentukan proses penegakan hukum adalah tidak hanya pihakpihak yang menerapkan hukum tetapi juga pihak-pihak yang membuat hukum. Dalam pembahasan ini dibicarakan mengenai pihak-pihak yang terkait langsung dengan penerapan hukum. Pihak-pihak dalam proses penegakan hukum dimaksud yaitu kepolisian, kejaksaan, kehakiman dan kepengacaraan. ${ }^{24}$

Jaksa selaku eksekutor untuk mencari cara bagaimana melakukan putusan. Dalam kaitannya dengan perkara ini Jaksa merasa sulit untuk melacak harta benda milik terpidana

${ }^{22}$ Penjelasan Umum Undang-undang No. 31 Tahun 1999

${ }^{23}$ Sidik Sunaryo, op.cit, hlm. 337

${ }^{24}$ Soerjono Soekanto, op.cit, hlm. 13 
yang diperoleh dari hasil tindak pidana korupsi. Setelah dilakukan pencarian harta benda oleh Jaksa Penuntut Umum tidak ditemukan adanya harta benda milik terdakwa untuk membayar uang pengganti. ${ }^{25}$

Ketiga, faktor masyarakat, yakni lingkungan di mana hukum tersebut berlaku atau diterapkan. Bagian terpenting dari masyarakat dalam yang menentukan penegakan hukum adalah kesadaran hukum masyarakat. Peraturan hukum yang berlaku atau diterapkan mempunyai pengaruh yang kuat terhadap pelaksanaan penegakan hukum. Sebab penegakan hukum berasal dari masyarakat dan bertujuan untuk mencapai kedamaian dan keadilan dalam masyarakat.

Kaitannya dengan faktor yang menjadi kendala efektivitas pelaksanaan/eksekusi pidana pembayaran uang pengganti dalam tindak pidana korupsi di Kejaksaan Negeri Purwokerto adalah kurangnya kesadaran dari masyarakat untuk melaporkan atau memberitahukan tindak pidana korupsi di lingkungannya serta harta benda yang dimiliki terdakwa, kepedulian atau kesadaran masyarakat untuk memberikan informasi secara dini kepada penegak hukum terhadap orang yang dicurigai melakukan tindak pidana korupsi masih kurang, justru ada kecenderungan untuk turut menutup-nutupi. ${ }^{26}$

Sehubungan dengan faktor masyarakat yang ikut mempengaruhi penegakan hukum ini, apabila dikaitkan dengan pendapat Friedman tentang unsur-unsur dalam sistem hukum yang salah satu unsurnya adalah "budaya hukum" yaitu sikap-sikap dan nilai yang berhubungan dengan hukum, yang datangnya dari rakyat atau pemakai jasa hukum, ${ }^{27}$ maka dapat di kemukakan bahwa budaya hukum masyarakat yang dicerminkan antara lain dengan sikap masyarakat yang enggan memberikan informasi tentang adanya pelaku tindak pidana korupsi atau harta benda yang dimiliki oleh pelaku kejabatan di lingkungannya, menunjukan adanya budaya hukum masyarakat yang belum mendukung pe-

\footnotetext{
${ }^{25}$ Wawancara dengan Kasi Pidsus pada Kejaksaan Negeri Purwokerto, 12 Januari 2010

${ }^{26}$ Wawancara dengan Kasi Pidsus pada Kejaksaan Negeri Purwokerto, 12 Januari 2010

${ }^{27}$ Abdul Manan, 2005, Aspek-aspek Pengubah Hukum, Yakarta: Prenada Media Group,. hlm. 9
}

negakan tindak pidana korupsi. Sehingga dapat dikatakan bahwa faktor masyarakat khususnya budaya hukum masyarakat merupakan faktor penghambat dalam penanggulangan tindak pidana korupsi.

Putusan penjatuhan pidana tambahan uang pengganti dalam putusan perkara korupsi di Pengadilan Negeri Purwokerto, uang pengganti yang seharusnya dikembalikan oleh terpidana kepada negara tidak seluruhnya mengembalikan, terdakwa ada yang tidak membayar uang pengganti sebagaimana terdapat dalam Putusan No. 112/Pid.B/2004/PN.Pwt, pembayaran uang pengganti belum terbayarkan dikarenakan terdakwa tidak mampu membayar, Putusan No. 73/Pid.B/2004/PN.Pwt, terdakwa tidak mampu membayar uang pengganti dan telah menjalani pidana subsidair, Putusan Nomor 113/Pid.B/2004/PN.Pwt, setelah dilakukan pencarian harta benda oleh JPU tidak ditemukan adanya harta benda untuk membayar uang pengganti.

Berdasarkan uraian tentang faktor-faktor yang menjadi kendala efektivitas pelaksanaan/ eksekusi pidana pembayaran uang pengganti dalam tindak pidana korupsi di Kejaksaan Negeri Purwokerto, maka dapat dikemukakan bahwa faktor-faktor tersebut meliputi tidak ada hambatan dari faktor hukumnya, karena Pemberantasan Tindak Pidana Korupsi telah memiliki dasar hukum yang kuat sehingga faktor ini tidak menjadi kendala yang menghambat tujuan dari pada undang-undang pemberantasan tindak pidana korupsi dalam rangka mempercepat pemberantasan korupsi di Indonesia. Hambatan dari faktor penegak hu-kum, yakni fihak-fihak yang membentuk maupun menerapkan hukum, Jaksa merasa sulit untuk melacak harta benda milik terpidana yang di peroleh dari hasil tindak pidana korupsi.

Hambatan dari faktor masyarakat, kurangnya kesadaran dari masyarakat untuk melaporkan atau memberitahukan tindak pidana korupsi di lingkungannya, kepedulian atau kesadaran masyarakat untuk memberikan informasi secara dini kepada penegak hukum terhadap orang yang dicurigai melakukan tindak pidana korupsi masih kurang. Terdakwa yang 
seharusnya mengembalikan uang pengganti namun tidak bisa membayar uang pengganti.

\section{Penutup}

\section{Simpulan}

Beberapa hal dapat disimpulkan dari pembahasan di atas. Pertama, jika ditinjau efektivitas daripada keberhasilan dalam pelaksanaan penjatuhan pidana pembayaran uang pengganti dalam tindak pidana di Pengadilan Negeri Purwokerto, maka hal tersebut dapat dikatakan belum efektif karena dari putusan yang menjatuhkan pidana pembayaran uang pengganti, terpidana yang membayar uang pengganti hanya 2 (dua) orang. Kedua, dalam putusan penjatuhan pidana tambahan pembayaran uang pengganti terpidana tidak mampu membayar, tidak mempunyai harta benda guna menutup pembayaran uang pengganti, adanya surat pernyataannya yang menerangkan tidak mampu membayar uang pengganti dari terpidana, dan akan menjalani pidana subsidair.; dan ketiga, Putusan Pengadilan Purwokerto dalam perkara tindak pidana korupsi tahun 2004, 2005, 2006, 2007 dan 2008, dalam putusan tersebut terpidana dijatuhi pidana tambahan berupa pembayaran uang pengganti. Dalam putusan tersebut ternyata tidak semua terpidana dijatuhi pidana tambahan pembayaran uang pengganti, tapi ada putusan penjatuhan pidana tanpa uang pengganti dan putusan bebas.

Ada beberapa faktor yang menjadi kendalam efektivitas pelaksanaan/eksekusi pidana pembayaran uang pengganti dalam tindak pidana korupsi di Kejaksaan Negeri Purwokerto. Pertama, hambatan dari faktor hukumnya, yaitu ketentuan Undang-Undang Nomor 31 Tahun 1999 tentang Pemberantasan Tindak Pidana Korupsi, dari faktor hukumnya sendiri telah memiliki dasar hukum yang kuat sehingga faktor ini tidak menjadi kendala yang meng-hambat tujuan dari pada undang-undang pemberantasan tindak pidana korupsi dalam rangka mempercepat pemberantasan korupsi di Indonesia; kedua, hambatan dari faktor penegak hukum, yakni fihak-fihak yang membentuk maupun menerapkan hukum, Jaksa merasa sulit untuk melacak harta benda milik terpidana yang diperoleh dari hasil tindak pidana korupsi; dan ketiga, hambatan dari faktor masyarakat, kurangnya kesadaran dari masyarakat untuk melaporkan atau memberitahukan tindak pidana korupsi di lingkungannya serta harta benda yang dimiliki terdakwa, kepedulian atau kesadaran masyarakat untuk memberikan informasi secara dini kepada penegak hukum terhadap orang yang dicurigai melakukan tindak pidana korupsi masih kurang. Terdakwa yang seharusnya mengembalikan uang pengganti namun tidak bisa membayar uang pengganti.

\section{Saran}

Dalam upaya untuk lebih mengefektifkan pelaksanaan pembayaran uang pengganti dalam tindak pidana korupsi, maka sumber daya manu-sia yang ada atau dimiliki institusi penegak hukum selain harus memiliki profesionalisme yang tinggi juga harus mempunyai integritas moral yang baik. Kinerja Jaksa selaku eksekutor harus lebih maksimal dalam melaksanakan tugas dengan dibekali pendidikan khusus yang ber-kaitan dengan bidang tugasnya khususnya dalam pelaksanaan pembayaran uang pengganti dalam tindak pidana korupsi. Perlu untuk semakin ditingkatkan aspirasi masyarakat untuk memberantas korupsi dan bentuk penyimpangan lainnya oleh lembaga penegak hukum dengan tetap menjunjung tinggi hak asasi manusia dan kepentingan masyarakat. 